\title{
Hypokalaemic Periodic Paralysis (A Case Report)
}

\author{
Partap Singh Ghalaut, Veena Singh Ghalaut, Sandeep Gupta
}

\begin{abstract}
Abstrak
Seorang lelaki muda berusia 20 tahun datang dengan keluhan kelemahan pada semua ekstremitasnya. Selama 2 tahun terakhir ini pasien telah mengalami 3 kali serangan yang berlangsung selama 4- 6 jam. Tidak ada riwayat penyakit yang sama dalam keluarga. Dibuat diagnosis paralisis periodik hipokalemik. Diberikan potassium intravena, dan profilaksis asetazolamide dengan hasil baik. Kasus ini tergolong jarang ditemukan.
\end{abstract}

\begin{abstract}
A case of young (20 years old) male presenting with dramatic onset of weakness in all the limbs is presented. Patient had three such episodes in the past 2 years lasting for 4-6 hrs. There was no family history of such weakness. A diagnosis of hypokalaemic periodic paralysis was made. Patient was given intravenous potassium, improved considerably and put on acetazolamide prophylaxis. The case is being reported because of its rarity and academic interest.
\end{abstract}

Keywords : Flaccid Paralysis, Potassium, Acetazolamide

\section{CASE REPORT}

A 20 year old male, was admitted on 6.5 .95 morning with history of intermittent fever associated with chills and rigors for 4 days and sudden onset of weakness in all four limbs since early morning. There was history of physical exertion on the day before the weakness. There was no history of respiratory difficulty, diplopia or difficulty in chewing and deglutition. There was no history of any urinary or bowel trouble. There was no history of increased apeptite, increased frequency of motions or tremors or weight loss. There was no history of seizures, headache, vomiting, unconsciousness or head injury. There was history of similar such episodes in the past; patient had 3 such episode in last 2 years, each of which subsided in 4-6 hours with treatment from Private Practitioner (P.P). There was no family history of such disease.

On examination, blood pressure was $100 / 60 \mathrm{mmHg}$ in right arm in supine position and heart rate was $64 / \mathrm{mt}$. regular with moderate volume pulse. Patient was fully conscious, and oriented well in time and space. There was no neck rigidity. Tone was decreased in all the four limbs. Deep tendon reflexes were diminished. Plantars were bilateral flexor and superficial abdominal

Pt.B.D. Sharma, PGIMS,

Rohtak-124001 Haryana, India reflexes were normal. Power grade II/V in right upper limb and $\mathrm{O} / \mathrm{V}$ in rest of limbs. There was no sensory loss. There was no signs of thyrotoxicosis.

\section{Investigations}

All investigations except serum Potassium (K) and Electrocardiograph (EKG) were within normal limits. Muscle biopsy also showed no significant change.

In view of previous episodic attacks of paralysis with spontaneous recovery, low $\mathrm{K}(2.5 \mathrm{mmol} / 1)$, slow heart rate $(64 / \mathrm{mt})$, flattened $T$ waves with prominent $U$ waves in EKG diagnosis of hypokalaemic periodic paralysis was made and patient was given intravenous potassium at the rate of $10 \mathrm{mmol}$ per hour. A total of $80 \mathrm{mmol}$ of $\mathrm{K}^{+}$were given and then patient put on oral potassium $15 \mathrm{mmol} 6 \mathrm{hrly}$. He became alright next day when his serum potassium was found to be $4 \mathrm{mmol} / \mathrm{l}$. Patient was then put on acetazolamide prophylaxis (250 $\mathrm{mgBD}$ ) and oral potassium; he has remained asymptomatic since then.

\section{DISCUSSION}

Hypokalaemic periodic paralysis has been reviewed by Engel $^{1-2}$ and Tome. ${ }^{3}$ It mostly occurs as a autosomal dominent disorder but may occur sporadically. In our case, there was no family history of such disorder and jt was a sporadic case. Typically, as happened in our case, 
the attacks usually begin in adolescent males. There is flaccid paralysis of all the voluntary muscles; speech, respiration and swallowing was not involved in our case as also reported in the literature. Muscle biopsy shows the presence of centrally placed vacuoles ${ }^{4}$ but can be normal $^{5}$ as in our patient. Commonly the attack begins in early morning and is precipitated by a period of rest following exertion (as in present patient) or after a heavy carbohydrate meal. Attacks are usually associated with a serum potassium of $<3.0 \mathrm{mmol} / 1 .^{5}$ Serum potassium was $2.5 \mathrm{mmol} / \mathrm{l}$ at the time of presentation in our case. Attacks last for 6-24 hrs, but severe ones can last for 2 to 3 days or even longer. ${ }^{5}$ Administration of $80 \mathrm{mmol}$ of potassium intravenously lead to prompt recovery in our case (in $24 \mathrm{hrs}$.).

The cause of this periodic hypokalaemic paralysis is not known completely, but may be due to excessive flux of $\mathrm{K}^{+}$from blood into muscles, ${ }^{6}$ probably due to abnormality in muscle membranes. There is no increase in urinary excretion of $\mathrm{K}^{+}$during or in between attacks as in our case also.

Spironolactone $25 \mathrm{mgm}$ QID or other aldosterone antagonists have been found to be useful in preventing attacks; ${ }^{7}$ but later on Acetazalamide (125-1000 mgm/ day in divided doses) was found to be more useful. ${ }^{8}$
The mechanism involved is that Acetazolamide induces metabolic acidosis, which lowers the rate of entry of potassium into the muscle cells.

\section{REFERENCES}

1. Engel AG. Metabolic and endocrine myopathies. In: Walton JN (ed) Disorders of voluntary muscle. Edinburg: Churchilllivingstone, $4^{\text {th }}$ edition.

2. Engel AG. Periodic paralysis. In: Engel AG, Armstrong CF (ed.). Myclogy. Vol.2. New York: McGraw Hill, 1994.

3. Tome FMS. In: Mastaglia and Walton JB (ed). Skeletal muscle pathology. Edinburg: Churchill-Livingstone, 1982.

4. Ptacek LJ, Griggs RC. Periodic paralysis. In: Harrison's Principles of Intemal Medicine. New York: McGraw Hill, 1994; 2396-8.

5. Mathew R, Gupta PS. Periodic paralysis - report of 6 cases. J Assoc Phys India 1979; 27: 663-7.

6. Grob D, Liljestrand A., Johns RJ. Potassium movement in patients with familial periodic paralysis. Am J Med 1957; 23: 356-75.

7. Poskanzer DC, Kerr DNS. Periodic paralysis with response to spironolactone. Lancet 1961; 2: 511-3.

8. Resnick JS, Engel WK, Griggs RC and Stam AC, Acetazolamide prophylaxis in hypokalaemic periodic paralysis. N Engl J Med 1968; 278: 582-6. 